\title{
Paprika and/or marigold extracts in diets for laying hens
}

\author{
Extratos de páprica elou marigold em dietas para poedeiras
}

\author{
OLIVEIRA, Maria Cristina de ${ }^{1^{*}}$; SILVA, Wanessa Dutra da ${ }^{1}$; OLIVEIRA, Higor Castro ${ }^{1}$; \\ MOREIRA, Eduardo de Queiroz Barros ${ }^{1}$; FERREIRA, Larissa de Oliveira ${ }^{1}$; GOMES, Yeury \\ de Sousa ${ }^{1}$; SOUZA JUNIOR, Marcos Aurélio Proto de ${ }^{2}$
}

\author{
${ }^{1}$ Universidade de Rio Verde, Faculdade de Medicina Veterinária, Rio Verde, Goiás, Brasil. \\ ${ }^{2}$ Universidade Federal de Goiás, Departamento de Medicina Veterinária, Goiânia, Goiás, Brasil. \\ *Endereço para correspondência: mcorv@yahoo.com.br
}

\section{SUMMARY}

This study was performed to evaluate the effect of the inclusion of paprika and marigold extracts in sorghum-based rations on the productivity and egg quality of laying hens. One hundred sixty laying hens were distributed in a completely randomized design in five treatments and in a factorial arrangement $(2 \times 2+1)$, one control ration based on corn, two levels of paprika extract $(0$ and $6 \mathrm{~g} / \mathrm{kg}$ diet), and two levels of marigold extract ( 0 and 1 $\mathrm{g} / \mathrm{kg}$ diet) in sorghum-based rations. There was no effect $(\mathrm{P}>0.05)$ of the treatments on the weight, specific weight, and Haugh unit of the eggs and productive performance, but the inclusion of paprika extract resulted in eggs with lower egg $\mathrm{pH}$. The interaction between the control group and the factorial was significant $(\mathrm{P}<0.05)$ to the laying rate, egg mass, and yolk color, whose values were lower with sorghum-based diets with no pigment compared to control treatment. The interaction between the paprika and marigold extracts was significant increasing the height $(\mathrm{P}<0.03)$ and color $(\mathrm{P}<0.0001)$ of the yolk when paprika extract was used, with or without marigold extract. Marigold extract inclusion reduced the percentage $(\mathrm{P}<0.02)$ and thickness $(\mathrm{P}<0.01)$ of the eggshell. As conclusion, the inclusion of paprika extract in sorghum-based diets for laying hens is viable for improving the egg quality.

Keywords: laying performance, natural pigment, vegetal extract

\section{RESUMO}

Este estudo foi realizado para avaliar o efeito da inclusão dos extratos de páprica e de marigold em rações a base de sorgo sobre a produtividade e qualidade de ovos de poedeiras. Cento e sessenta poedeiras foram distribuídas em delineamento inteiramente ao acaso em cinco tratamentos e em um arranjo fatorial $(2 \times 2+1)$, uma ração controle a base de milho, dois níveis de extrato de páprica (0 e $6 \mathrm{~g} / \mathrm{kg}$ dieta) e dois níveis de extrato de marigold (0 e $1 \mathrm{~g} / \mathrm{kg}$ dieta) em rações a base de sorgo. Não houve efeito $(\mathrm{P}>0,05)$ dos tratamentos sobre $\mathrm{o}$ peso, peso específico e unidade Haugh dos ovos e desempenho produtivo, mas a inclusão de extrato de páprica resultou em ovos com menor $\mathrm{pH}$. A interação entre o grupo controle e o fatorial foi significante $(\mathrm{P}<0,05)$ para taxa de postura, massa de ovo e cor de gema, cujos valores foram menores com dietas a base de sorgo sem pigmentos comparado ao tratamento controle. A interação entre os extratos de páprica e marigold foi significante aumentando a altura $(\mathrm{P}<0,03)$ e cor $(\mathrm{P}$ $<0,0001)$ da gema quando o extrato de páprica foi usado, com ou sem extrato de marigold. A inclusão de extrato de marigold reduziu a porcentagem $(\mathrm{P}<$ $0,02)$ e espessura $(\mathrm{P}<0,01)$ da casca. Como conclusão, a inclusão de extrato de páprica em dietas a base de sorgo para poedeiras é viável por melhorar a qualidade do ovo.

Palavras-chave: desempenho de poedeiras, extratos vegetais, pigmentos naturais 


\section{INTRODUCTION}

Sorghum, sometimes used as a corn substitute, is poor in carotenoids, resulting in slightly pigmented yolks, and according to Englmaierová et al. (2014) yolk color is an important quality factor, followed by freshness and eggshell quality.

Studies point to side effects of the consumption of artificial pigments (PINHEIRO, 2012). Ingestion of tartrazine and crepuscule yellow may cause allergic reactions (PRADO \& GODOY, 2007). The erytrosine intake resulted in failures in the reproduction of male mice due the reduction of the testicular activity and spermatozoids motility (ABDEL-AZIZ et al., 1997).

The use of natural pigments has increased due the consumer's concerns about the negative effects of the artificial pigments to their health (DUFOSSÉ, 2006). Marigold and paprika are natural pigments. Paprika (Capsicum annuum) contains small amounts of red pigments and great quantities of yellow carotenoids (GONZÁLES et al., 1999). Marigold (Tagetes erecta L.) is a plant commonly used in yolk pigmentation and contains $4200 \mathrm{mg} / \mathrm{kg}$ carotenoids (GÖCER et al., 2006). Xanthophylls in the yolk comprise lutein and zeaxanthin (HADDEN et al., 1999) and marigold is one of the most concentrated of sources of lutein $(80 \%$ to $90 \%$ lutein) (ALTUNTA \& AYDIN, 2013).

The capsaicinoids in the paprika extract have antioxidant effects (COSTA et al., 2010) and reduces the plasmatic cholesterol levels and the formation of atheromatous plaque in human being (HUANG et al., 2014). Several reports revised the safety of lutein for adults (JECFA, 2006; SHAO \& HATHCOCK, 2006). A study concluded that $200 \mathrm{mcg} / \mathrm{L}$ lutein in formulations for babies is safe (EFSA, 2008).

Working with sorghum-based diets containing paprika extract, Moreno et al.
(2007) reported that hen productivity and egg quality were not affected, except by the yolk color, which increased with inclusion of paprika in the diets. Aderemi et al. (2013) studied paprika in hen diets and verified that its inclusion increased the laying rate and Haugh unit and reduced the cholesterol content in the yolk when compared with diets based on corn. Evaluating the effect of marigold extract (10 and $20 \mathrm{~g} / \mathrm{kg}$ ) for laying, Altuntas \& Aydin (2014) noted that egg weight decreased with the use of $20 \mathrm{~g} / \mathrm{kg}$ marigold but yolk color intensified. This study was performed to evaluate the effect of paprika extract and marigold extract in sorghumbased rations on the productivity and egg quality of laying hens.

\section{MATERIAL AND METHODS}

The experimental trial was approved by the Institutional Animal Ethics Committee (No. 11-14; 05 November 2014) of the University of Rio Verde and conducted under its guidelines.

One hundred sixty Hy-Line W36 laying hens, 95 weeks of age, were distributed in metallic cages for 28 days with a density of four birds per cage. Each cage was $101 \mathrm{x}$ $44 \times 44 \mathrm{~cm}$ in length, width, and height, respectively.

The experimental design was completely randomized with five treatments in a factorial arrangement $(2 \times 2+1)$, one control ration based on corn, and two levels of paprika extract ( 0 and $6 \mathrm{~g} / \mathrm{kg}$ diet) $x$ two levels of marigold extract ( 0 and $1 \mathrm{~g} / \mathrm{kg}$ diet) in sorghum-based rations (Table 1), with four replicates comprised of two cages with four birds each one. The commercial product Sun Gold ${ }^{\circledR}$ and Sun $\operatorname{Red}^{\circledR}$ (Seifun Comércio e Indústria Ltda, São Paulo, Brasil). contained marigold extract (Tagetes erecta) and paprika extract (Capsicum annum) as yellow and red natural colorants, respectively. Experimental rations were formulated 
based on the Rostagno et al. (2011) recommendations for light laying hens. Rations and water were provided ad libitum during the experimental period. Hens received continuous light program with 16 hours of light (natural + artificial). The daily ration consumption, feed conversion rate, laying rate, and egg mass were evaluated. Egg weight was obtained with all the eggs layed on the three last days of the experimental period. Specific gravity was determined using 10 eggs per replicate, totaling 40 eggs per treatment. $\mathrm{pH}$ of the eggs; percentage of yolk, albumen, and eggshell; yolk color, and eggshell thickness, height, and diameter of yolk and albumen were evaluated at the end of the experimental period using five eggs per replicate, totaling 20 eggs per treatment.

Table 1. Composition of the experimental diets containing paprika and/or marigold extracts

\begin{tabular}{|c|c|c|c|c|c|}
\hline Ingredients & $\begin{array}{l}\text { Control } \\
\text { ration }\end{array}$ & $\begin{array}{l}\text { Sorghum based } \\
\text { ration }(\mathrm{S})\end{array}$ & $\begin{array}{c}\mathrm{S}+\text { paprika } \\
\text { extract }\end{array}$ & $\begin{array}{c}\mathrm{S}+\text { marigold } \\
\text { extract }\end{array}$ & $\begin{array}{c}\mathrm{S}+\text { paprika }+ \\
\text { marigold } \\
\text { extract }\end{array}$ \\
\hline Corn & 60.60 & - & - & - & - \\
\hline Sorghum & - & 60.25 & 60.25 & 60.25 & 60.25 \\
\hline Soybean meal & 25.00 & 23.60 & 23.60 & 23.60 & 23.60 \\
\hline Soybean oil & 2.24 & 4.00 & 4.00 & 4.00 & 4.00 \\
\hline Dicalcium phosphate & 1.18 & 1.15 & 1.15 & 1.15 & 1.15 \\
\hline Limestone & 9.38 & 9.40 & 9.40 & 9.40 & 9.40 \\
\hline Common salt & 0.50 & 0.50 & 0.50 & 0.50 & 0.50 \\
\hline DL-methionine & 0.10 & 0.10 & 0.10 & 0.10 & 0.10 \\
\hline Mineral premix ${ }^{1}$ & 0.20 & 0.20 & 0.20 & 0.20 & 0.20 \\
\hline Vitamin premix ${ }^{2}$ & 0.10 & 0.10 & 0.10 & 0.10 & 0.10 \\
\hline Paprika extract & - & - & 0.60 & - & 0.60 \\
\hline Marigold extract & - & - & - & 0.10 & 0.10 \\
\hline Inert & 0.70 & 0.70 & 0.10 & 0.60 & 0.00 \\
\hline Total & 100 & 100 & 100 & 100 & 100 \\
\hline \multicolumn{6}{|l|}{ Calculated composition $^{3}$} \\
\hline Crude protein $(\%)$ & 16.02 & 16.02 & 16.02 & 16.02 & 16.02 \\
\hline $\begin{array}{l}\text { Metabolizable energy } \\
(\mathrm{kcal} / \mathrm{kg})\end{array}$ & 2805 & 2805 & 2805 & 2805 & 2805 \\
\hline Calcium (\%) & 3.9 & 3.9 & 3.9 & 3.9 & 3.9 \\
\hline Available phosphorus (\%) & 0.3 & 0.3 & 0.3 & 0.3 & 0.3 \\
\hline Sodium $(\%)$ & 0.2 & 0.2 & 0.2 & 0.2 & 0.2 \\
\hline Total lysine (\%) & 1.0 & 1.0 & 1.0 & 1.0 & 1.0 \\
\hline Total methionine $(\%)$ & 0.4 & 0.4 & 0.4 & 0.4 & 0.4 \\
\hline Price (U\$/kg) & 0.18 & 0.16 & 0.19 & 0.17 & 0.21 \\
\hline \multicolumn{6}{|c|}{$\begin{array}{l}\text { each } \mathrm{kg} \text { contain: Fe } 20000 \mathrm{mg} \text {, I } 120 \mathrm{mg} \text {, } \mathrm{Cu} 1600 \mathrm{mg} \text {, Mn } 24000 \mathrm{mg}, \mathrm{Zn} 16000 \mathrm{mg} \text {, Se } 20 \mathrm{mg} \text {, Co } 20 \mathrm{mg} \text {. } \\
2 \text { each } \mathrm{kg} \text { contain: vit } \mathrm{A} 20000000 \mathrm{UI} \text {, vit } \mathrm{D}_{3} 5000000 \mathrm{UI} \text {, vit E } 40500 \mathrm{UI} \text {, vit } \mathrm{K}_{3} 4800 \mathrm{mg} \text {, vit } \mathrm{B}_{1} 3600 \mathrm{mg} \text {, vit } \\
\mathrm{B}_{2} 12000 \mathrm{mg} \text {, vit } \mathrm{B}_{6} 6000 \mathrm{mg} \text {, vit } \mathrm{B}_{12} 28000 \mathrm{mcg} \text {, niacin } 87000 \mathrm{mg} \text {, biotin } 60 \mathrm{mg} \text {, pantothenic acid } 29000 \mathrm{mg} \text {, } \\
\text { folic acid } 1600 \mathrm{mg} \text {. } \\
{ }^{3} \text { According to Rostagno et al. (2011). }\end{array}$} \\
\hline
\end{tabular}

For evaluating the yolk color, a colorimetric fan with a scale from 1 to 15 degrees was used. Two whole eggs were used to determine the egg $\mathrm{pH}$. The eggshells of two eggs per replicate were washed and dried for weight and thickness measures. The thickness of eggshells was measured at three points (on both pole and lateral regions) using a digital caliper (Digimess, $0.01 \mathrm{~mm}$ precision). The weight of the albumen was determined by subtracting the weight of the yolk and eggshell from the egg weight. 
The Haugh unit was obtained using the formula $\mathrm{HU}=100 \times \log \left(\mathrm{H}-1.7 \times \mathrm{W}^{0.37}+\right.$ 7.6), where $H$ is the length of the albumen $(\mathrm{mm})$ and $\mathrm{W}$ is the weight of the whole egg (g). Specific weight $\left(\mathrm{g} / \mathrm{cm}^{3}\right)$ was determined by the immersion of the eggs in receptacles containing different saline solutions $(\mathrm{NaCl})$, whose densities varied from 1.050 to 1.100 , with intervals of 0.005 .

The results of the factorial arrangement paprika $\times$ marigold were submitted to ANOVA using the software SISVAR (FERREIRA, 2011), and when there was significant interaction between the factors, the comparison among means was performed using the Tukey test at 5\% probability. To compare the means of the factorial arrangement and the control treatment, the Dunnett test was applied, also at $5 \%$ probability.

\section{RESULTS AND DISCUSSION}

The inclusion of paprika and/or marigold extracts did not influence $(\mathrm{P}>0.05)$ the laying hens' productivity; however, the interaction between the control treatment and factorial was significant $(\mathrm{P}<0.02)$ to the laying rate and egg mass, where the values obtained with the sorghum-based diets with no pigments were $9.9 \%$ and $14 \%$ lower than the values obtained with the control diet (Table 2).

Table 2. Productivity of laying hens fed corn- or sorghum-based diets containing paprika and/or marigold extracts

\begin{tabular}{|c|c|c|c|c|c|c|}
\hline \multirow{2}{*}{ Parameters ${ }^{2}$} & \multirow{2}{*}{ Control diet } & \multirow{2}{*}{ Paprika extract } & \multicolumn{2}{|c|}{ Marigold extract } & \multirow{2}{*}{ Mean } & \multirow{2}{*}{$\begin{array}{c}\text { CV } \\
(\%)^{1}\end{array}$} \\
\hline & & & $0.0 \%$ & $0.1 \%$ & & \\
\hline \multirow[t]{3}{*}{$\operatorname{DRC}(\mathrm{g} / \mathrm{d})$} & & $0.0 \%$ & 126.03 & 135.36 & 130.69 & \\
\hline & & $0.6 \%$ & 137.40 & 121.06 & 129.23 & \\
\hline & 148.59 & Mean & 131.72 & 128.21 & & 5.95 \\
\hline \multirow[t]{3}{*}{ FCR $(\mathrm{kg} / \mathrm{kg})$} & & $0.0 \%$ & 2.88 & 2.92 & 2.90 & \\
\hline & & $0.6 \%$ & 2.87 & 2.67 & 2.77 & \\
\hline & 3.00 & Mean & 2.87 & 2.80 & & 5.75 \\
\hline \multirow[t]{3}{*}{ FCR (kg/dz) } & & $0.0 \%$ & 2.31 & 2.42 & 2.36 & \\
\hline & & $0.6 \%$ & 2.35 & 2.15 & 2.25 & \\
\hline & 2.49 & Mean & 2.33 & 2.28 & & 5.79 \\
\hline \multirow[t]{3}{*}{ LR $(\%)$} & & $0.0 \%$ & $64.43 *$ & 66.86 & 65.65 & \\
\hline & & $0.6 \%$ & 70.06 & 68.02 & 69.05 & \\
\hline & 71.51 & Mean & 67.25 & 67.45 & & 5.04 \\
\hline \multirow[t]{3}{*}{ EM (g/ave/d) } & & $0.0 \%$ & $42.73 *$ & 46.02 & 44.38 & \\
\hline & & $0.6 \%$ & 48.19 & 45.36 & 46.77 & \\
\hline & 49.68 & Mean & 45.46 & 45.69 & & 6.66 \\
\hline
\end{tabular}

${ }^{1} \mathrm{CV}=$ coefficient of variation.

${ }^{2} \mathrm{DRC}=$ daily ration consumption, $\mathrm{FCR}=$ feed conversion rate, $\mathrm{LR}=$ laying rate, $\mathrm{EM}=$ egg mass.

*Differ from control treatment by Dunnett test.

The availability of amino acids, such as lysine and methionine, in sorghum is lower than in corn because the protein in the endosperm is found more adhered to the starch granules in sorghum (NADEEM et al., 2005). In addition, sorghum also has a lower energy value than corn (ROSTAGNO et al., 2011). These characteristics contribute to the lower 
laying rate and consequent reduction in egg mass.

Similar results were found by Englmaierová \& Skrivan (2013), who used lutein, present in marigold extract, in diets for laying hens at $250 \mathrm{mg} / \mathrm{kg}$ and did not notice effects on the birds' productivity. Skrivan et al. (2015) studied the inclusion of 150,250 , and $350 \mathrm{mg} / \mathrm{kg}$ of marigold extract in laying hen diets and also did not observe improvements in the productive performance of the hens when compared with treatment based on corn.

There was no effect $(\mathrm{P}>0.05)$ of the treatments on the weight, specific weight, and Haugh unit of the eggs; however, the inclusion of paprika extract resulted in eggs with lower $\mathrm{pH}$ (Table 3 ).

Table 3. Egg quality of laying hens fed corn- or sorghum-based diets containing paprika and/or marigold extracts

\begin{tabular}{|c|c|c|c|c|c|c|}
\hline \multirow{2}{*}{ Parameters } & \multirow{2}{*}{ Control } & \multirow{2}{*}{$\begin{array}{c}\text { Paprika } \\
\text { extract }\end{array}$} & \multicolumn{2}{|c|}{ Marigold extract } & \multirow{2}{*}{ Mean } & \multirow{2}{*}{$\begin{array}{l}\mathrm{CV} \\
(\%)^{1}\end{array}$} \\
\hline & & & $0.0 \%$ & $0.1 \%$ & & \\
\hline \multirow[t]{3}{*}{ Egg weight (g) } & & $0.0 \%$ & 66.30 & 68.82 & 67.56 & \\
\hline & & $0.6 \%$ & 68.66 & 66.75 & 67.71 & \\
\hline & 69.49 & Mean & 67.48 & 67.78 & & 3.72 \\
\hline \multirow[t]{3}{*}{ Egg $\mathrm{pH}$} & & $0.0 \%$ & 7.70 & 7.97 & $7.83 \mathrm{a}$ & \\
\hline & & $0.6 \%$ & 7.52 & 7.38 & $7.45 \mathrm{~b}$ & \\
\hline & 7.68 & Mean & 7.61 & 7.67 & & 4.17 \\
\hline \multirow[t]{3}{*}{ Egg specific weight $\left(\mathrm{g} / \mathrm{cm}^{3}\right)$} & & $0.0 \%$ & 1.082 & 1.077 & 1.079 & \\
\hline & & $0.6 \%$ & 1.074 & 1.077 & 1.075 & \\
\hline & 1.081 & Mean & 1.078 & 1.077 & & 0.37 \\
\hline \multirow[t]{3}{*}{ Egg Haugh unit } & & $0.0 \%$ & 96.06 & 90.55 & 93.31 & \\
\hline & & $0.6 \%$ & 91.67 & 92.88 & 92.27 & \\
\hline & 86.10 & Mean & 93.86 & 91.72 & & 5.66 \\
\hline
\end{tabular}

${ }^{\mathrm{I}} \mathrm{CV}=$ coefficient of variation.

Means followed by different letters are different by Tukey test.

Niu et al. (2008) included $0.1 \%, 0.2 \%$, $0.4 \%$, and $0.8 \%$ of paprika extract in laying hen diets and reported that the carotenoid content in the yolk was linearly increased from $3.43 \mathrm{mg} / \mathrm{g}$ in the treatment with no paprika extract to $16.83 \mathrm{mg} / \mathrm{g}$ in the $0.8 \%$ treatment. Carotenoids have an antioxidant action that is important to reduce the lipid oxidation rate in the yolk and the ovalbumin degradation. These reactions lead to water and $\mathrm{CO}_{2}$ losses, with subsequent elevation of $\mathrm{pH}$ in the egg. The interaction paprika $\times$ marigold was significant to the height $(\mathrm{P}<0.03)$ and color $(\mathrm{P}<0.0001)$ of the yolk (Table 4$)$. The inclusion of marigold extract in the diets with no paprika extract did not result in a higher yolk height; however, when paprika extract was added together with marigold extract, the quantum of yolk was $8.34 \%$ higher. The same effect was observed by comparing the inclusion of paprika extract in diets regardless of whether they contained marigold extract.

As for yolk color, the inclusion of marigold extract improved the yolk color in eggs of hens fed diets with no paprika extract $(2.00 \times 8.81)$; however, the inclusion (or not) of marigold extract in diets containing paprika extract did not result in an improvement of yolk pigmentation $(14.25 \times 14.00)$. It was also noted that the inclusion of paprika extract, with or without marigold extract, greatly improved the yolk color, when compared 
with the results obtained with diets with no paprika.

The interaction control $\times$ factorial was significant $(\mathrm{P}<0.0001)$ to yolk color. The pigmentation of the yolks obtained with diets containing only marigold did not differ from the color obtained with the control treatment, and the eggshells of the birds that consumed diets with sorghum without pigments was thicker than the eggshells of eggs obtained with the control treatment.

Table 4. Yolk, albumen, and eggshell quality of laying hens fed diets based on sorghum and containing paprika and/or marigold extract

\begin{tabular}{|c|c|c|c|c|c|c|}
\hline \multirow{2}{*}{ Parameters } & \multirow{2}{*}{ Control } & \multirow{2}{*}{$\begin{array}{l}\text { Paprika } \\
\text { level (\%) }\end{array}$} & \multicolumn{2}{|c|}{ Marigold level (\%) } & \multirow{2}{*}{ Mean } & \multirow{2}{*}{$\begin{array}{l}\mathrm{CV} \\
(\%)^{1}\end{array}$} \\
\hline & & & 0.0 & 0.1 & & \\
\hline \multicolumn{7}{|l|}{ Yolk } \\
\hline \multirow[t]{3}{*}{ Percentage $(\%)$} & & 0.0 & 26.11 & 25.66 & 25.88 & \\
\hline & & 0.6 & 26.07 & 27.30 & 26.69 & \\
\hline & 26.53 & Mean & 26.09 & 26.48 & & 6.54 \\
\hline \multirow[t]{3}{*}{ Height (mm) } & & 0.0 & $18.50^{\mathrm{Aa}}$ & $18.13^{\mathrm{Ba}}$ & 18.31 & \\
\hline & & 0.6 & $18.00^{\mathrm{Ab}}$ & $19.50^{\mathrm{Aa}}$ & 18.75 & \\
\hline & 18.25 & Mean & 18.25 & 18.81 & & 4.03 \\
\hline \multirow[t]{3}{*}{ Diameter (mm) } & & 0.0 & 44.25 & 44.00 & 44.12 & \\
\hline & & 0.6 & 43.87 & 44.37 & 44.12 & \\
\hline & 44.50 & Mean & 44.06 & 44.18 & & 3.07 \\
\hline \multirow[t]{3}{*}{ Color } & & 0.0 & $2.00^{\mathrm{Bb} *}$ & $8.81^{\mathrm{Ba}}$ & 5.41 & \\
\hline & & 0.6 & $14.25^{\mathrm{Aa} *}$ & $14.00^{\mathrm{Aa} *}$ & 14.12 & \\
\hline & 8.25 & Mean & 8.12 & 11.41 & & 4.46 \\
\hline \multicolumn{7}{|l|}{ Albumen } \\
\hline \multirow[t]{3}{*}{ Percentage $(\%)$} & & 0.0 & 64.14 & 65.77 & 64.95 & \\
\hline & & 0.6 & 64.64 & 63.59 & 64.11 & \\
\hline & 64.27 & Mean & 64.39 & 64.68 & & 2.82 \\
\hline \multirow{3}{*}{ Height (mm) } & & 0.0 & 9.62 & 8.65 & 9.14 & \\
\hline & & 0.6 & 8.87 & 9.00 & 8.94 & \\
\hline & 8.12 & Mean & 9.25 & 8.83 & & 5.35 \\
\hline \multirow[t]{3}{*}{ Diameter (mm) } & & 0.0 & 97.87 & 101.06 & 99.47 & \\
\hline & & 0.6 & 100.50 & 102.12 & 101.31 & \\
\hline & 100.62 & Mean & 99.18 & 101.59 & & 5.53 \\
\hline \multicolumn{7}{|l|}{ Shell } \\
\hline \multirow[t]{3}{*}{ Percentage (\%) } & & 0.0 & 9.75 & 8.55 & 9.15 & \\
\hline & & 0.6 & 9.28 & 9.11 & 9.19 & \\
\hline & 9.19 & Mean & $9.51^{\mathrm{a}}$ & $8.83 b$ & & 5.16 \\
\hline \multirow[t]{3}{*}{ Thickness (mm) } & & 0.0 & 0.447 & 0.410 & 0.428 & \\
\hline & & 0.6 & 0.432 & 0.413 & 0.448 & \\
\hline & 0.420 & Mean & $0.440^{\mathrm{a}}$ & $0.411^{\mathrm{b}}$ & & 5.17 \\
\hline
\end{tabular}

${ }^{\mathrm{I}} \mathrm{CV}=$ coefficient of variation.

Means followed by lowercase and capital letter in the line and rows, respectively, differ by Tukey test.

*Differ of the control treatment by Dunnett test. 
The diet with corn promoted yolk with a colorimetric score of 8.25; however, when sorghum was used, the color score decreased (2.00). When paprika and marigold extracts were added to sorghumbased diets, yolk pigmentation was higher; however, there was no associative effect of both pigments. Paprika extract was more efficient in yolk pigmentation than marigold extract. Lokaewmanee et al. (2011) noted that there was no associative effect of paprika and marigold on the egg yolk; however, different results were found by Moura et al. (2011), who reported an associative effect of both extracts.

Different results were reported by Englmaierová \& Skrivan (2013) and Skrivan et al. (2015), who obtained more colored yolk with the inclusion of marigold extract in laying hen diets when compared with the values obtained with corn-based diets.

Marigold extract inclusion reduced the percentage $(\mathrm{P}<0.02)$ and thickness $(\mathrm{P}<$ $0.01)$ of the eggshell. The quality of the shell is affected by several factors, such as illness, nutritional status of the flock, heat stress, and bird age (ROBERTS, 2004). According to reports, lutein and zeaxanthin, carotenoids present in marigold extract, inhibit the estrogenic activity in several tissues (HIRSCH et al., 2007; SHARONI et al., 2012; VEPRIK et al., 2012; ZHANG et al., 2012); this is probably the reason for the lower percentage and thickness of the eggshell.

The shell consists mainly of calcium carbonate $\left(\mathrm{CaCO}_{3}\right)$. The carbonic anidrase (CA) are enzymes that help in eggshell formation, and Benesch et al. (1944) demonstrated that $\mathrm{CA}$ inhibition in hens resulted in eggs with soft shells as this enzyme catalyzes the hydration of the metabolic $\mathrm{CO}_{2}$ to $\mathrm{HCO}_{3}{ }^{-}$, the precursor of the carbonate in the shell. Carbonate is transported and attached to the calcium in the mucosa of the eggshell gland (EASTIN $\&$ SPAZIANI, 1978). The CA action in the eggshell gland is regulated by the $17 \beta$ estradiol (E2) in the endometrium in rats and Guinea pigs (PINCUS \& BIALY, 1963; HODGEN \& FALK, 1971). In laying hens, daidzein, a phytoestrogen, increases the CA number in the capillaries in the eggshell gland (WISTEDT et al., 2012).

As conclusion, the inclusion of paprika extract in sorghum-based diets is viable for improving the egg $\mathrm{pH}$ and yolk color. Marigold extract, however, reduces the eggshell quality.

\section{REFERENCES}

ABDEL-AZIZ, A.H.; SHOUMAN, S.A.; ATTIA, A.S.; SAAD, S.E. A study on the reproductive toxicity of erythrosine in male mice. Pharmacological Research, v.35, n.5, p.457-462, 1997.

ADEREMI, F.; ALABI, O.; AYOOLA, O. Evaluation pepper (Capsicum annuum) and garlic (Allium sativum) on performance egg trait and serum parameters of old layers. Journal of Biology, Agriculture and Healthcare, v.3, n. 7, p.90-95, 2013.

ALTUNTAS, A.; AYDIN, R. Fatty acid composition of egg yolk from chickens fed a diet including marigold (Tagetes erecta L.). Journal of Lipids, v.2014, Article ID 564851, p.1-4, 2014. doi.org/10.1155/2014/564851.

BENESCH, R.; BARRON, N.S.; MAWSON, C.A. Carbonic anhydrase, sulphonamides and shell formation in the domestic fowl. Nature, v.153, n.3874, p.138-139, 1944.

COSTA, L.M.; MOURA, N.F.; MARANGONI, C.; MENDES, C.E.; TEIXEIRA, A.O. Atividade antioxidante de pimentas do gênero Capsicum. Ciência e Tecnologia de Alimentos, v.30, supl. 1, p.51-59, 2010. 
DUFOSSÉ, L. Microbial production of food grade pigments. Food Technology and

Biotechnology, v.44, n.3, p.313-321, 2006.

EASTIN, W.C. Jr; SPAZIANI, E. On the mechanism of calcium secretion in the avian shell gland (uterus). Biology of

Reproduction, v.19, n.3, p.505-518, 1978.

\section{EUROPEAN FOOD SAFETY}

AUTHORITY - EFSA. Opinion of the scientific panel on dietary products, nutrition and allergies on a request of the Commission related to safety, bioavailability and suitability of lutein for the particular nutritional use by infants and young children. The EFSA Journal, v.823, n.1, p.1-24, 2008.

ENGLMAIEROVÁ, M.; BUBANCOVÁ, I.; SKRIVAN, M. Carotenoids and egg quality. Acta Fytotechique Zootechnique, v.17, n.2, p.55-57, 2014.

ENGLMAIEROVÁ, M.; SKRIVAN, M. Effect of synthetic carotenoids, lutein, and mustard on the performance and egg quality. Scientia Agriculturae Bohemica, v.44, n.3, p.138-143, 2013.

FERREIRA, D.F. Sisvar: a computer statistical analysis system. Ciência \& Agrotecnologia, v.35, n.6, p.1039-1042, 2011.

GÖCER, M.; YANAR, M.; KUMLU, M.; YANAR, Y. The effects of red pepper, marigold flower, and synthetic astaxanthin on pigmentation, growth, and proximate composition of Penaeus semisulcatus. Turkish Journal of Veterinary and Animal Science, v.30, n.4, p.359-365, 2006.

GONZÁLES, M.; CASTAÑO, E.; AVILA, E.; MEJÍA, E.G. Effect of capsaicin from red pepper (Capsicum sp.) on the deposition of carotenoids in egg yolk. Journal of the Science of Food and Agriculture, v.79, n.13, p.1904-1908, 1999.
HADDEN, W.L.; WATKINS, R.H.; LEVY, L.W.; REGALADO, E.; RIVADENEIRA, D.M.; van BREEMEN, R.B.; SCHWARTZ, S.J. Carotenoid composition of Marigold (Tagetes erecta) flowers extract used as nutritional supplement. Journal of Agricultural and Food Chemistry, v.47, n.10, p.4189-4194, 1999.

HIRSCH, K.; ATZMON, A.; DANILENKO, M.; LEVY, J.; SHARONI, Y. Lycopene and other carotenoids inhibit estrogenic activity of $17 \beta$-estradiol and genistein in cancer cells. Breast Cancer Research and Treatment, v.104, n.2, p.221-230, 2007.

HODGEN, G.D.; FALK, R.J. Estrogen and progesterone regulation of carbonic anhydrase isoenzymes in guinea pig and rabbit uterus. Endocrinology, v.89, n.3, p.859-864, 1971.

HUANG, W.; CHEANG, W.S.; WANG, X.; LEI, L.; LIU, Y.; MA, K.Y.; ZHENG, F.; HUANG, Y.; CHEN, Z.Y. Capsaicinoids but not their analogue capsinoids lower plasma cholesterol and possess beneficial vascular activity.

Journal of Agricultural and Food Chemistry, v.62, n.33, p.8415-5420, 2014.

JECFA - Joint FAO/WHO Expert Committee on Food Additives. Lutein from Tagetes erecta L. WHO Food Additives Series, v.54, n.1, p.49-86, 2006. Available at:

$<$ http://www.fao.org/ag/agn/jecfaadditives/specs/monograph3/additive255.pdf $>$. Acesso em: 25/10/2014.

LOKAEWMANEE, K.; YAMAUCHI, K.; KOMORI, T.; SAITO, K. Enhancement of egg yolk color by paprika combined with a probiotic. Journal of Applied Poultry Research, v.20, n.1, p.90-94, 2011. 
MORENO, J.O.; ESPÍNDOLA, G.B.; SANTOS, M.S.V.; FREITAS, E.R.; GADELHA, A.C.; SILVA, F.M.C. Desempenho e qualidade dos ovos de poedeiras comerciais, alimentadas com dietas contendo sorgo e páprica em substituição ao milho. Acta Scientiarum.Animal Science, v.29, n.2, p.159-163, 2007.

MOURA, A.M.A.; TAKATA, F.N.; NASCIMENTO, G.R.; SILVA, A.F.; MELO, T.V.; CECON, P. R. Pigmentantes naturais em rações à base de sorgo para codornas japonesas em postura. Revista Brasileira de Zootecnica, v.40, n.11, p.2443-2449, 2011.

NADEEM, A.; RAJ.H.; CHHABRA, S. Increased oxidative stress and altered levels of antioxidants in chronic obstructive pulmonary disease.

Inflammation, v.29, n.1, p.23-32, 2005.

NIU, Z.; FU, J.; GAO, Y.; LIU, F. Influence of páprica extract supplement on egg quality of laying hens fed wheat-based diet. International Journal of Poultry Science, v.7, n.9, p.887-889, 2008.

PINCUS, G.; BIALY, G. Carbonic anhydrase in steroid-responsive tissues. Recent Progress in Hormone Research, v.19, n.1, p.201-250, 1963.

PINHEIRO, M.C.O. Avaliação da exposição aos corantes artificiais por crianças entre 3 e 9 anos em relação ao consumo de balas. 2012. 98f. Dissertação (Mestrado em Vigilância Sanitária) Instituto Nacional de Controle de Qualidade em Saúde, Fundação Oswaldo Cruz, Rio de Janeiro.

PRADO, M.A.; GODOY, H.T. Corantes artificiais em alimentos. Alimentação e Nutrição, v.14, n.2, p.237-250, 2003.
ROBERTS, J.R. Factors affecting egg internal quality and egg shell quality in laying hens. Journal of Poultry Science, v.41, n.3, p.161-177, 2004.

ROSTAGNO, H.S.; ALBINO, L.F.T.; DONZELE J.L.; GOMES, P.C.;

OLIVEIRA, R.F.; LOPES, D.C.; FERREIRA, A.S.; BARRETO, L.S.T.; EUCLIDES, R.F. Tabelas brasileiras para aves e suínos: composição de alimentos e exigências nutricionais. Viçosa: Universidade Federal de Viçosa, 2011. 252p.

SHAO, A.; HATHCOCK, J. N. Risk assessment for the carotenoids lutein and lycopen. Regulatory Toxicology and Pharmacology, v.46, n.3, p.289-298, 2006.

SHARONI, Y.; LINNEWIEL-HERMONI, K.; ZANGO, G.; KHANIN, M.; SALMAN, H.; VEPRIK, A.; DANILENKO, M.; LEVY, J. The role of lycopene and its derivatives in the regulation of transcription systems: implications for cancer prevention.

American Journal of Clinical Nutrition, v.96, n.5, p.1173S-1178S, 2012.

SKRIVAN, M.; ENGLMAIEROVÁ, M.; SKRIVANOVÁ, E.; BUBANCOVÁ, I. Increase in luetin and zeaxanthin contente in the eggs of hens fed marigold flower extract. Czech Journal of Animal

Science, v.60, n.3, p.89-96, 2015.

VEPRIK, A.; KHANIN, M.; LINNEWIEL-HERMONI, K.; DANILENKO, M.; LEVY, J.; SHARONI, Y. Polyphenols, isothiocyanates, and carotenoid dierivatives enhance estrogenic activity in bone cells but inhibit it it breast cancer cells. American Journal of Physiology: Endocrinology and Metabolism, v.303, n.7, p.E815-E824, 2012. 
WISTEDT, A.; RIDDERSTRÄLE, Y.;

WALL, H.; HOLM, L. Effects of phytoestrogen supplementation in the feed on the shell gland of laying hens at the end of the laying period. Animal

Reproduction Science, v.133, n.3-4, p.205-213, 2012.

ZHANG, X.; SPIEGELMAN, D.; BAGLIETTO, L.; BERNSTEIN, L.; BOGGS, D.A.; van den BRANDT, P.; BURING, J.E.; GAPSTUR, S.M.; GILES, G.G.; GIOVANNUCCI, E.; GOODMAN, G.; HANKINSON, S.E.; HELZLSOUER, K.J.; HOM-ROSS, P.L.; INOUE, M.;

JUNG, S.; KHUDYAKOV, P.;

LARSSON, S.C.; LOF, M.;

McCULLOUGH, M.L.; MILLER, A.B.;

NEUHOUSER, M.L.; PALMER, J.R.;

PARK, Y.; ROBIEN, K.; ROHAN, T.E.;

ROSS, J.A.; SCHOULTEN, L.J.;

SHIKANY, J.M.; TSUGANE, S.;

VISVANATHAN, K.; WEIDERPASS, W.; WOLK, A.; WILLETT, W.C.;

ZHANG, S.M.; ZIEGLER, R.G.; SMITH-

WARNER, S.A. Carotenoid intakes and

risk of breast cancer defined by estrogen

receptor and progesterone receptor status: a

pooled analysis of 18 prospective cohort

studies. American Journal of Clinical

Nutrition, v.95, n.3, p.713-725, 2012.

Data de recebimento: 01/09/2016

Data de aprovação: 27/04/2017 